\title{
Hot Water in the Long Valley Caldera-The Benefits and Hazards of this Large Natural Resource
}

\begin{abstract}
The volcanic processes that have shaped the Long Valley Caldera in eastern California have also created an abundant supply of natural hot water. This natural resource provides benefits to many users, including power generation at the Casa Diablo Geothermal Plant, warm water for a state fish hatchery, and beautiful scenic areas such as Hot Creek gorge for visitors. However, some features can be dangerous because of sudden and unpredictable changes in the location and flow rate of boiling water. The U.S. Geological Survey monitors several aspects of the hydrothermal system in the Long Valley Caldera including temperature, flow rate, and water chemistry.
\end{abstract}

The Long Valley Caldera is a large, oval-shaped depression formed 767,000 years ago during a massive volcanic eruption. The caldera stretches northeastward from Mammoth Mountain to Glass Mountain, a distance of nearly 20 miles (32 kilometers). A central highland known as the resurgent dome and numerous smaller hills within the caldera reflect subsequent volcanic activity; for example, Doe Ridge near the Mammoth Yosemite Airport, is built from lava erupted 300,000 years ago. The Hot Creek Geologic Site, a U.S. Forest Service managed recreation area, is located at the north end of Doe Ridge. Volcanic eruptions in the past 10,000 years have also created the visually impressive Inyo Craters chain that trends north from the town of Mammoth Lakes.

\section{The Hydrothermal System in Long Valley Caldera}

In any volcanic system, only a part of the magma (molten rock) erupts at the land surface. What remains underground slowly solidifies and loses heat to surrounding rocks. At Long Valley, snowmelt on the western caldera rim infiltrates deep underground and absorbs a large amount of heat and gases (like carbon dioxide) released from the residual magma. A 1-mile-deep well

The boiling springs in Hot Creek are scenic but can erupt unpredictably. Because of this danger, the U.S. Forest Service closed parts of the area to visitors. Photograph courtesy of U.S. Forest Service.

(44-16, see map on page 2) drilled near the Inyo Craters chain encountered water at temperatures near $428^{\circ} \mathrm{F}\left(220^{\circ} \mathrm{C}\right)$.

The heated water is naturally buoyant and rises from depth, but before it can reach the surface, it encounters highly permeable rock layers that channel the flow eastward. Along the way, the elevation of the land surface and thus the pressure on the water drops, allowing the water to boil. Some steam and gas reaches the land surface in the vicinity of Shady Rest Park, at the east edge of the town of Mammoth Lakes. Steam upflow has created approximately 12 acres (nearly 50,000 square meters) of thermal ground near the park, where trees and other vegetation have died.

Before geothermal power production began, the hot water discharged from hot springs at Casa Diablo, but these have turned to steaming gas vents (fumaroles) as the water level has been drawn down. A small amount of hot water warms the spring-fed ponds at the Hot Creek State

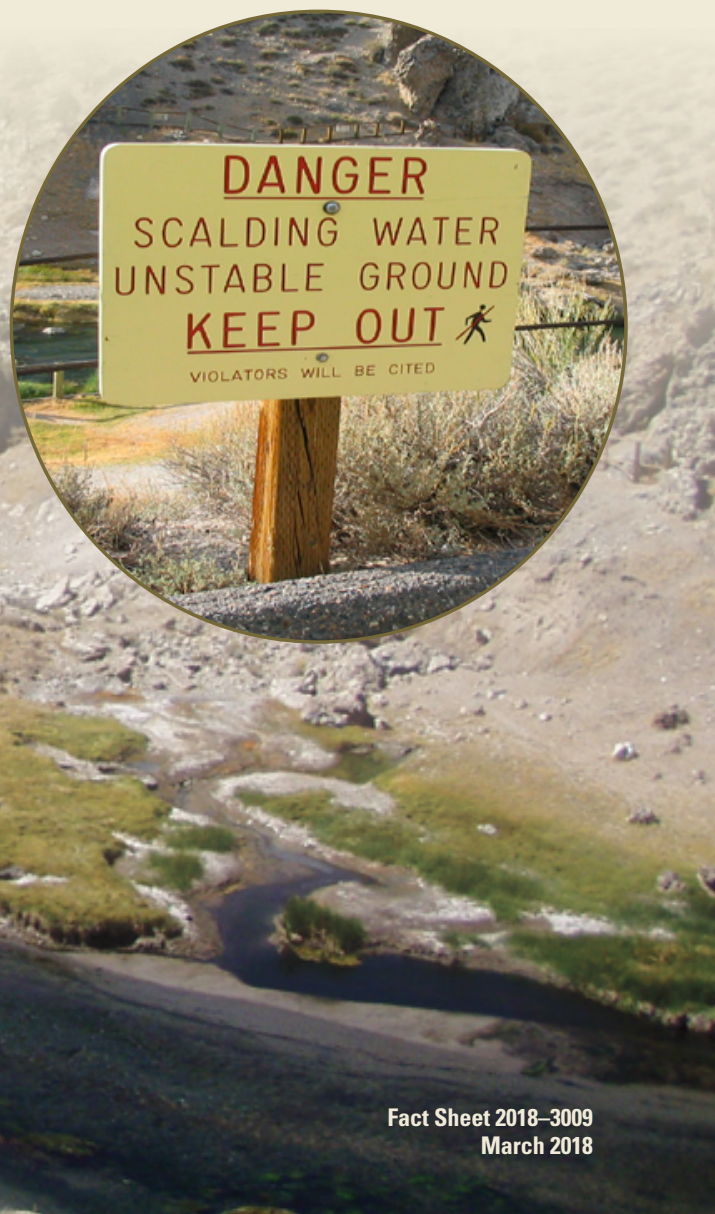


Fish Hatchery. However, the main point of discharge is the Hot Creek Geologic Site, where Hot Creek has cut a gorge that intersects the underground hot water flowpath. The hot springs in the gorge discharge a total of 64 gallons (242 liters) of water per second - enough to fill eight Olympic-size swimming pools each day. Hot water that does not discharge in Hot Creek gorge comes out at a number of hot and warm springs as far east as the shores of Crowley Lake. This large volume of hot water distinguishes Long Valley Caldera from most other volcanic systems, where hot springs may be common but release much less water.

\section{Benefits of Natural Hot Water}

The geothermal plant at Casa Diablo operates production wells that bring the hot water to the surface, where the heat is used to generate electricity. The cooled water is then injected back into the ground. The success of this operation, which began in 1985, has led to expansion of the plant's power production capabilities to the present net capacity of about 30 megawatts, enough to power 22,000 homes. Increased production from new wells near Shady Rest Park is expected to substantially boost generating capacity.

The Hot Creek State Fish Hatchery relies on the naturally heated water to maintain fish growth rates throughout the winter months, when low air temperatures would otherwise make the ponds too cold. The trout from these geothermally heated ponds are then released to local lakes and streams, including Hot Creek, where they provide recreational enjoyment for fishing enthusiasts.

The Hot Creek Geologic Site, managed by the U.S. Forest Service, is a scenic stop for visitors to see the boiling hot springs and fumaroles along Hot Creek gorge. The site offers excellent opportunities for hiking, wildlife viewing, photography, and of course, exploring the local geology. Some hot springs and pools have beautiful aprons of travertine (calcium carbonate) deposited by the mineralized waters. Additional hot springs can be found within a few miles of the Hot Creek Geologic Site. Many are frequently visited by the public and have long been known to Native Americans, who have accorded them special status and spiritual significance.

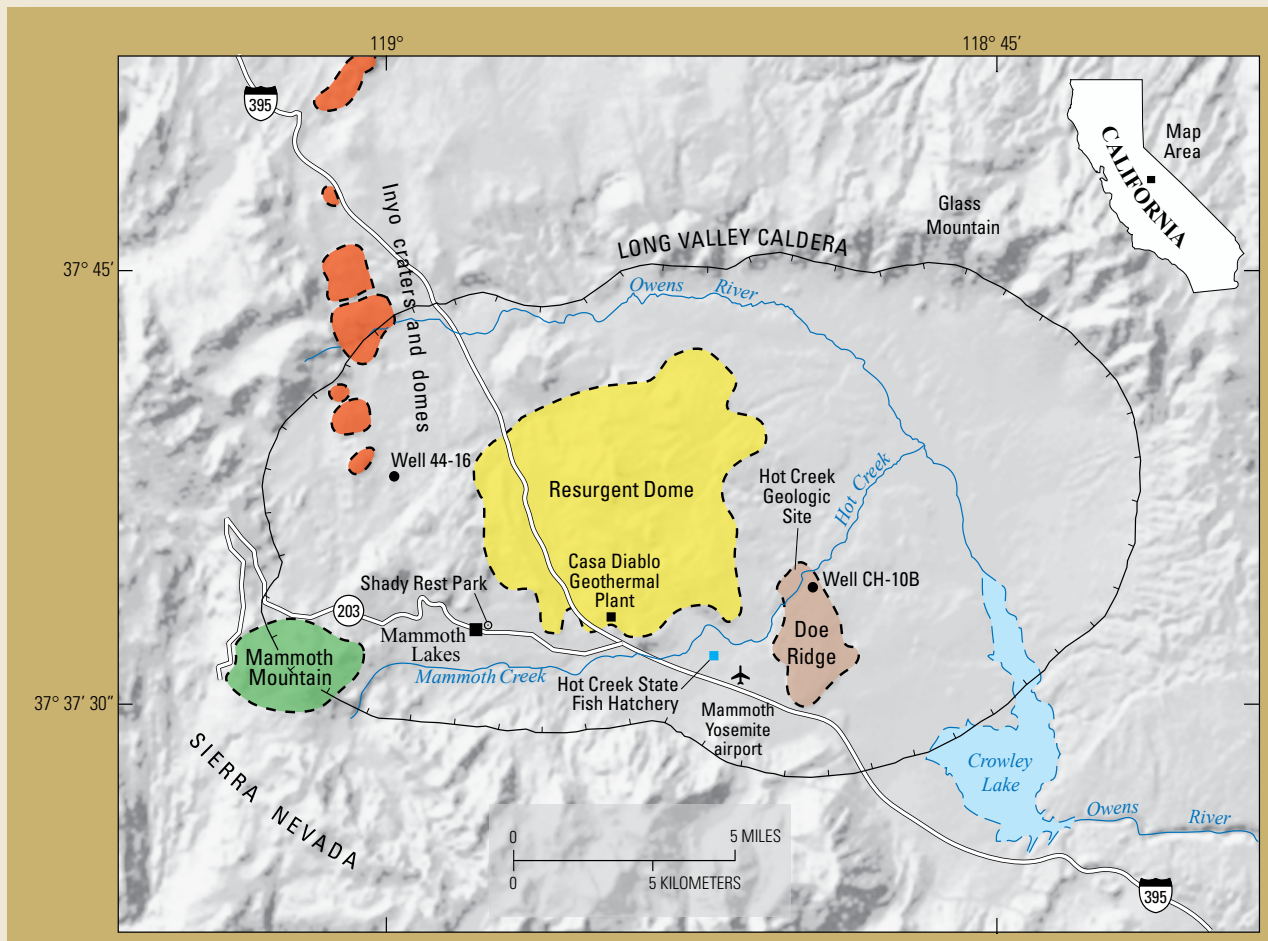

Simplified geologic map (top) and cross section (bottom) of Long Valley Caldera. The resurgent dome, Doe Ridge, and the Inyo craters and domes all reflect volcanic activity since 767,000 years ago, when a giant eruption formed the caldera. The hot springs in Hot Creek are fed by Sierra Nevada snowmelt that seeps underground, is heated to at least $428^{\circ} \mathrm{F}\left(220^{\circ} \mathrm{C}\right)$ in the vicinity of molten rock (magma), and flows eastward beneath the ground (red arrows). The temperature of the water reaching the springs at Hot Creek could be affected by earthquake activity, geothermal heat extraction, mixing with cooler water, and other factors.

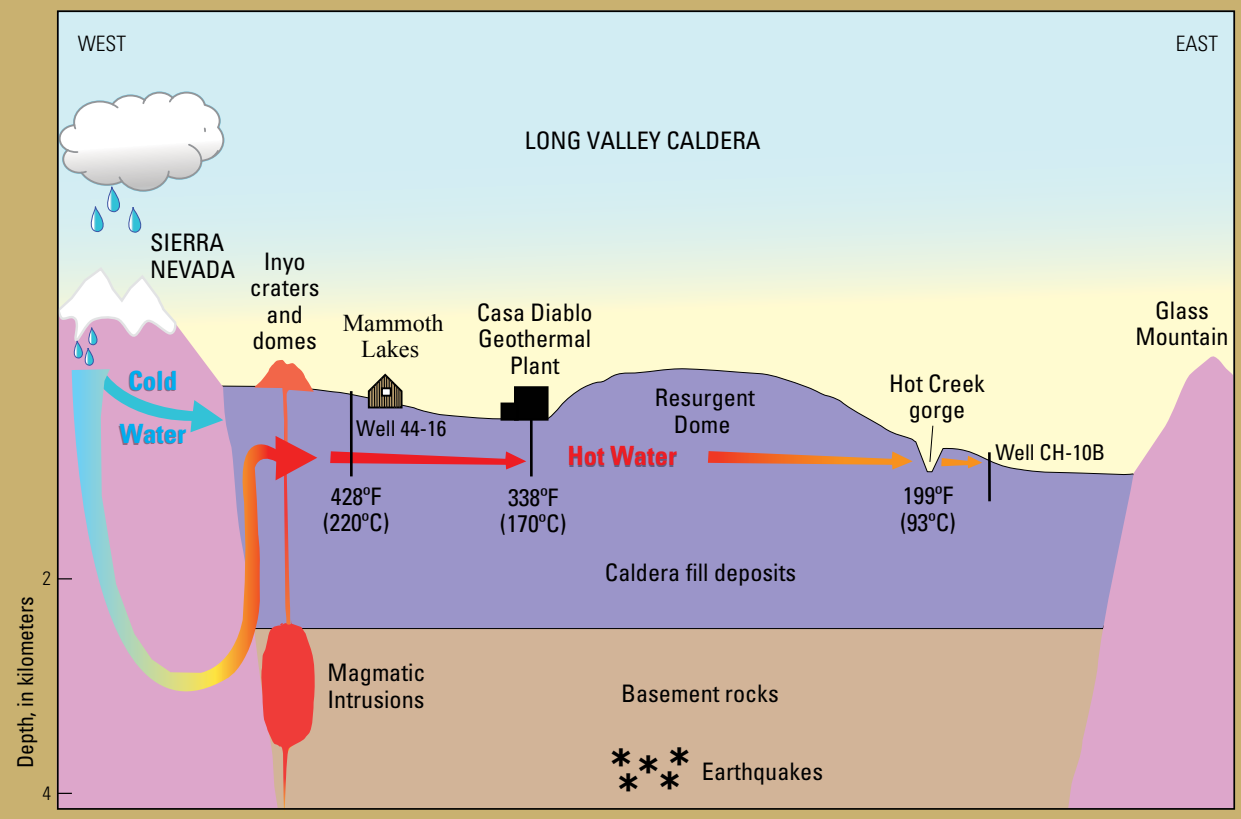

\section{Hazards of Natural Hot Water}

The presence of natural hot water in Long Valley Caldera is most apparent to the public at the Hot Creek Geologic Site. This is also where the hazard to the public is greatest. Boiling springs line both sides of the creek, and additional springs are concealed on the creek bottom. The hot water from these submerged springs mixes into the cold creek and creates deceptively 


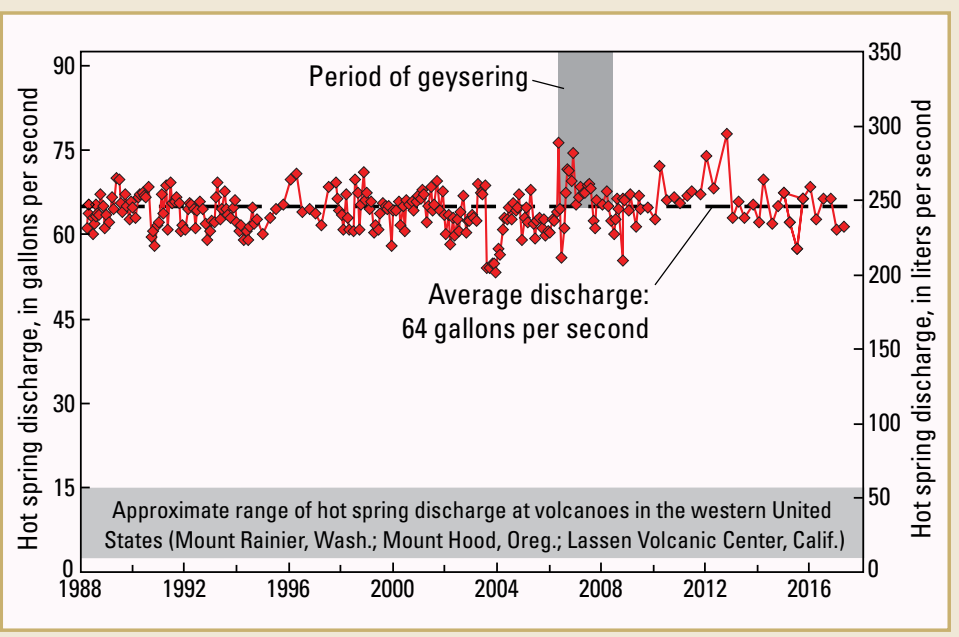

The total discharge of hot water into Hot Creek shows small variations over time but has averaged 64 gallons (242 liters) per second (dashed line) since U.S. Geological Survey monitoring began. The onset of geysering in May 2006 corresponded to a small spike in discharge, but geysering was not linked to a similar spike 6 years later.

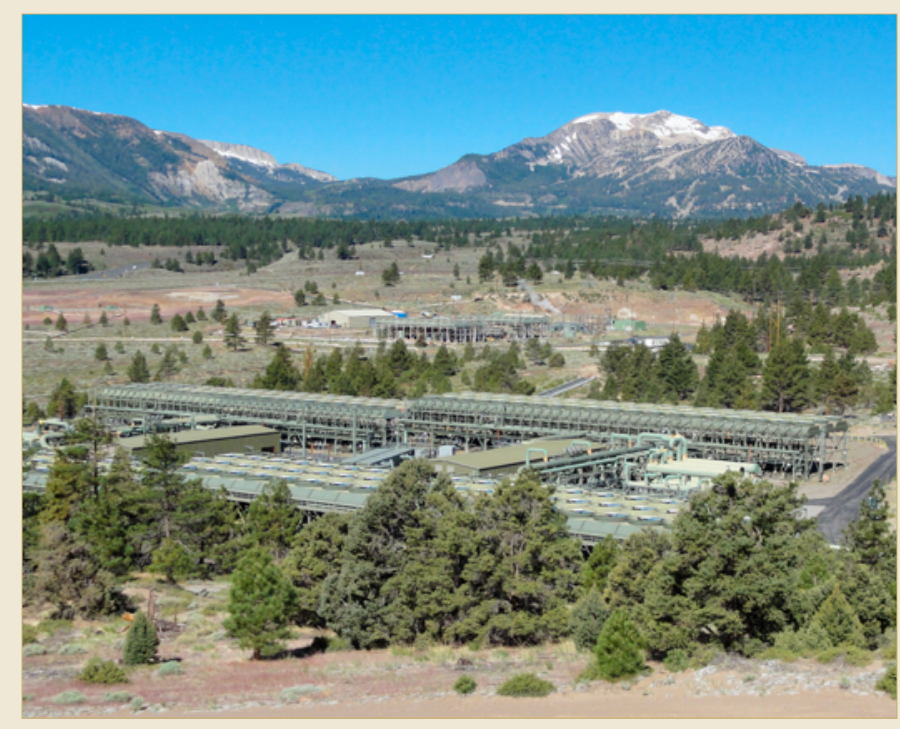

The geothermal power plant at Casa Diablo, looking west toward Mammoth Mountain. Photograph by James Howle, U.S. Geological Survey. comfortable swimming conditions. However, very rapid increases in spring discharge can sometimes raise water temperatures high enough to scald, killing unlucky fish and other organisms. Be careful that you do not fall victim to such a fate!

In May 2006, the stream bottom springs began to geyser intermittently, spraying very hot, sediment-laden water as much as 6 feet ( 2 meters) above the stream surface. The unpredictability of the geysering and the clear hazard to swimmers and streamside spectators soon led the U.S. Forest Service to close parts of the Hot Creek Geologic Site to protect public safety. Fences and signs were installed or relocated to keep visitors away from unstable banks that can collapse without warning into newly formed pools of boiling water. Although the geysering activity gradually declined with time and has not been observed in recent years, the constant and unpredictable shifting of hot spring vents makes it imperative that visitors observe all safety guidelines and closures posted by the U.S. Forest Service. Similar episodes of geysering in Hot Creek occurred in the 1930s and early 1980s, the latter of which coincided with a period of intense earthquake activity and deformation of the ground surface, and will likely happen again in the future.

\section{USGS Monitoring}

USGS scientists monitor water temperatures in the hot springs and in nearby observation well $\mathrm{CH}-10 \mathrm{~B}$ (see map). They also monitor the total discharge from all the hot springs in the gorge. The onset of geysering in May 2006 was accompanied by a small spike in total hot spring discharge and occurred as the temperature at the water surface in well $\mathrm{CH}-10 \mathrm{~B}$ reached the local boiling point. The ultimate cause of the temperature increase is not known. Earthquake activity is known to alter groundwater flow paths, and diversion of flow through hotter rocks could have raised water
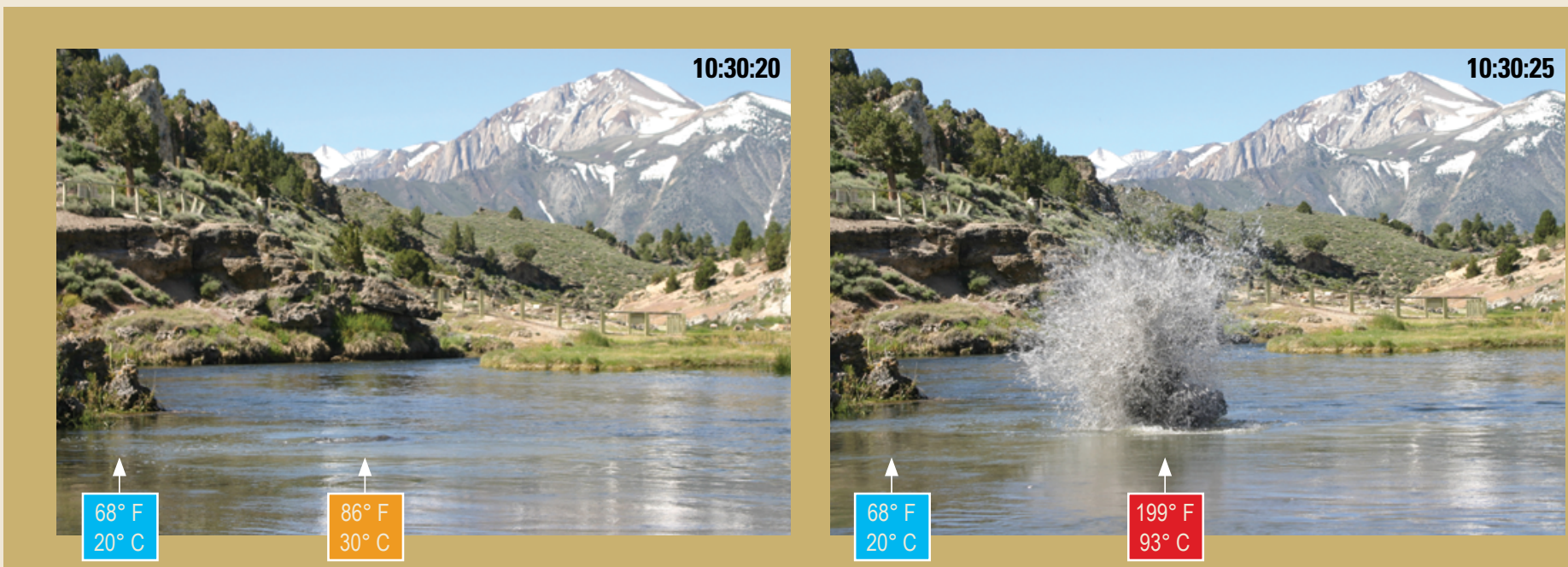

The temperature in Hot Creek can change rapidly as shown in these photos taken 5 seconds apart. Water at $199^{\circ} \mathrm{F}\left(93^{\circ} \mathrm{C}\right)$, the boiling point at this elevation, erupted above the creek during the violent geysering event. Any swimmer caught in this part of the creek would have been severely scalded. Photographs courtesy of Alix Ginter. 


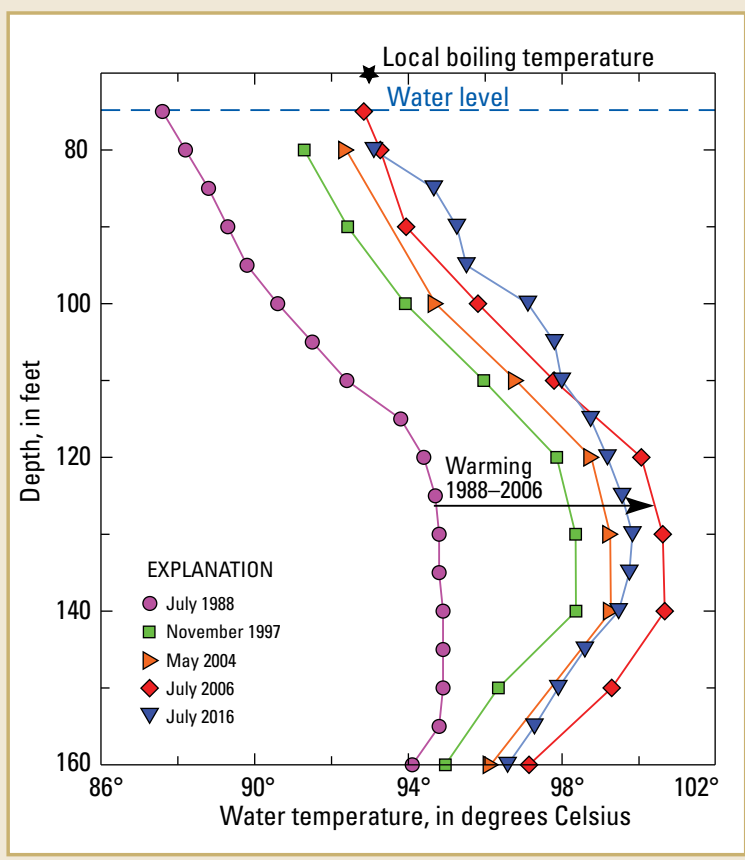

temperatures. Although May 2006 was a time of low earthquake activity, a delayed response to earthquakes that occurred west of Hot Creek gorge in previous years is possible, given that the underground flow of water is slow.

Additionally, the USGS assesses how geothermal power production affects the hot springs - their temperature, flow rates, and chemistry - as well as the local environment and groundwater resources. This part of the monitoring program is coordinated through the Long Valley Hydrologic Advisory Committee (LVHAC) organized by Mono County. The USGS must also determine
Temperatures in the upper 90 feet (below water level) in well $\mathrm{CH}-10 \mathrm{~B}$ showed a gradual increase between 1988 and 2006 . The top of the water column reached the local boiling point about the time that geysering began in Hot Creek (May 2006), suggesting a direct connection. However, temperatures in well $\mathrm{CH}-10 \mathrm{~B}$ have remained high since 2006 , even as geysering has ceased. if changes in hydrothermal activity could be a prelude to volcanic activity; this part of the monitoring program is coordinated within the USGS California Volcano Observatory (CalVO), which continuously assesses the hazard at the many volcanoes in California and Nevada.

Renewed volcanic activity is a concern at Long Valley, where the resurgent dome inside the caldera has been pushed upward nearly 3 feet ( 1 meter) in the past four decades, and some eruptions of lava along the Inyo Craters chain are less than 700 years old.

Magma must rise from great depth to the surface before it can erupt, and rising magma is an abundant source of heat and gases like carbon dioxide, which can ascend in advance of the magma itself. If the hydrothermal system intercepts the rising heat and gas, it could respond by getting hotter and more gas rich; therefore, CalVO monitors the temperature as well as the water and gas chemistry in various springs and wells, and soil temperatures and release of carbon dioxide in areas of thermal ground.
Background photograph. Dying trees show continuing expansion of an area of thermal ground and diffuse carbon dioxide gas emissions near Shady Rest Park in 2017. The expansion likely results from changing groundwater levels and does not indicate increased volcanic activity. Photograph by Deborah Bergfeld, U.S. Geological Survey. Inset photograph. USGS scientist measuring the flow of carbon dioxide in an area of thermal ground.
Over the many years of monitoring, both increases and decreases in well temperatures have been observed and the areas of thermal ground have expanded. However, these changes likely do not signify increased volcanic unrest and can be attributed to the impacts of earthquakes and geothermal energy production on groundwater flowpaths. The USGS continues to monitor the hydrothermal system, not only to better understand the cause of anomalous events like the Hot Creek geysering, but also to provide accurate hazard and resource assessments to land managers.

\section{By William C. Evans, Shaul Hurwitz, Deborah Bergfeld, and James F. Howle Edit and layout by Katherine Jacques Figures by Linda Masonic}

For more information, contact:

U.S. Geological Survey

California Volcano Observatory

345 Middlefield Road, MS-910

Menlo Park, CA 94025 